\title{
The IBM story
}

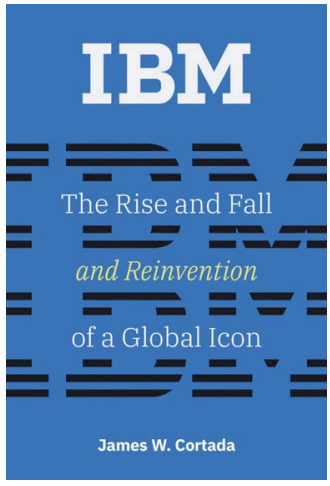

\author{
IBM: The Rise \\ and Fall and \\ Reinvention of a \\ Global Icon \\ By James W. \\ Cortada \\ MIT PRESS: 2019. \\ 752PP. $€ 35.00$
}

he history of IBM is a well-trodden topic in the history of computing. Most books on the subject have focused on the firm's technologies, especially the many computers it designed and commercialized. With IBM: The Rise and Fall and Reinvention of a Global Icon, James Cortada instead provides a business-centred history of the corporation. Cortada is a well-known historian of computing, and the author of numerous books on the computer industry and the introduction of computing into different economic sectors. He is also an IBM insider. For nearly forty years, he worked as an IBM salesman, consultant, and manager. This unusual combination makes for a detailed and insightful narrative. It also makes for an impassioned one. Like many IBMers, Cortada is proud of the company's accomplishments and he remains deeply attached to his former employer. But he is also critical of current management, which he believes has strayed from the formula that made IBM such a powerful and long-lasting corporation: customer orientation and a deep respect for employees.

Since its formation in 1911, IBM has navigated its way - with varying degrees of success - through three successive data processing platforms: tabulating technology, mainframe computing, and more recently distributed computing. The firm originated as a trust, a merger of several small corporations, that aimed to control the US market for office machinery. Its crown jewel was the mechanical equipment for automatic data handling, which was inherited from one of its constituent firms, the Tabulating Machine Company. Thomas Watson Sr, the company's CEO from 1914 to 1956 , shaped IBM into a fearsome sales machine and built a quasi-monopoly in the market of tabulating equipment. $\mathrm{He}$ made gutsy decisions, such as continuing to invest in new technology and inventory during the Great Depression. This risky bet paid off as IBM won major contracts for data processing equipment from the Social Security Administration and other Federal agencies in the US during the New Deal (reforms to restore prosperity that began in 1933). Wartime demand further fuelled IBM's growth in the first half of the 1940s.

After World War II, IBM made a successful transition to an entirely different data handling technology: electronic computing. Cortada argues that Thomas Watson Jr, the son of IBM's long-time CEO, and a group of hand-picked managers drove that transformation. They restructured the corporation and adroitly used military investments in computer technology to establish IBM as a major manufacturer of large digital computers, the mainframes. Betting the corporation like his father had done during the Great Depression, Thomas Watson Jr initiated the design and fabrication of a new line of computers named System/360. The System/360 line made IBM's own machines, as well as those of its competitors, obsolete, and set the standard for mainframes globally, including in Japan and the Soviet Union. System/360 also transformed IBM into the dominant player in the global computer industry from the 1960 s to the 1980 s.

Despite this success, IBM nearly missed the technological shift to distributed computing. The introduction of the PC in 1981 was a promising start, but the firm quickly lost its early lead to Compaq and other start-ups. Cortada argues that reasons for this reversal were many. The new generation of IBM's upper managers, men such as John Opel and John Akers who had made their careers in the mainframe business, did not comprehend the dispersal of computing brought about by small machines. They let IBM's bureaucratic structure stifle the development of personal computers, slowing down the introduction of new products. They also made strategic mistakes, such as failing to secure rights to the PC's main components, Intel's microprocessors and Microsoft's operating system, and refusing to invest in Microsoft. Deepening IBM's predicament were the massive investments Opel and Akers made in mainframe design and manufacturing in the first half of the 1980s.

Saddled by these unproductive investments and losing its lead in computing to Intel and Microsoft, IBM nearly collapsed in the late 1980s and early 1990s. It had to lay off 200,000 employees in order to survive. Starting in 1992, Louis Gerstner, IBM's new CEO, revived the corporation by reorientating it toward software and IT services. And his successors followed suit. Over the last two decades, IBM has remained a major player in computing and is still a very large and profitable corporation with a high market capitalization. But the shift from hardware to IT services came at a cost, according to Cortada. IBM's upper managers invested less in innovation, slashed employee benefits, and shifted employment from the United States to India, where labour costs were lower. They also increasingly repurchased IBM's own stock, to the tune of US $\$ 162$ billion between 1997 and 2018, in order to increase its value.

IBM: The Rise and Fall and Reinvention of a Global Icon is a good read. It is engaging and replete with juicy tidbits. The detailed discussion about sales, arguably the firm's most influential function and its main source of competitiveness for much of the twentieth century, is the book's key contribution to the literature on IBM. Cortada also aptly shows how critical customers were in shaping IBM's response to emerging technologies. For example, the large corporations using IBM's tabulating equipment urged the Thomas Watsons to move into digital computers. Later, these customers spurred the shift to novel storage technologies such as magnetic tape and disk drives. They also instigated the company's entry into personal computers.

Cortada is less persuasive when he depicts IBM as an ethical firm committed to the welfare of its employees. IBM was clearly a paternalistic organization until the late 1980s. But this does not mean that it had the best interest of its employees at heart. Occupational health research has, in particular, suggested that workers involved in the manufacture of IBM computers may have been exposed to harmful chemicals, which have subsequently had a detrimental effect on their health.

\section{Reviewed by Christophe Lécuyer \\ Sorbonne Université, Paris, France. \\ e-mail:chrlecuyer@protonmail.com}

Published online: 17 May 2019 https://doi.org/10.1038/s41928-019-0251-0 